UDC 621.316

\title{
RESEARCH OF THE NON-SINUSOIDAL LOADS IMPACT ON THE OPERABILITY OF TAP-CHANGERS CONTACTS
}

\section{ZINOVKIN V.V.}

BLYZNIAKOV O.V.
Doctor of Technical Science, Professor, Professor of the department "Electric drive and automation of industrial installations" of the National University "Zaporizhzhia Polytechnic", Zaporizhzhia, Ukraine, e-mail: super_znvvv@ukr.net;

Candidate of Technical Science, associate professor, associate professor of the department "Electric and electronic apparatus" of the National University "Zaporizhzhia Polytechnic", Zaporizhzhia, Ukraine, e-mail: blizn1953@gmail.com;

Purpose. To establish quantitative indicators of the influence of non-sinusoidal loads on the parameters and operability of contacts of voltage control devices of transformers of power-consuming electrical installations

Methodology. In our research, we used the probabilistic-statistical methods to analyze the experimental findings. Experimental studies were carried out applying advanced software-based methods for processing, systematizing and visualizing the findings derived.

Findings. The analysis of the accident rate of transformers for power-consuming technological installations showed that adjustable transformers, in particular, on-load tap-changers, are in many cases the cause of failure in the operation of electrical installations. On the example of a switching device of the RNOA-110/1250 type, it was experimentally established that the non-sinusoidality of the current caused by abruptly alternating loads, in combination with an increase in the number of switchings, leads to an increase in the contact resistance, which significantly reduces the reliability and serviceability of contacts.

Originality. The dependence of the transient resistance of the contacts of the voltage control device under the load of the transformer on the degree of non-sinusoidality of the load current is obtained.

Practical value. The results of the work can be used in the development of new designs of on-load tap-changers for special purpose operation under conditions of load fluctuations. In particular, the work is aimed to increase the reliability of on-load tap changers contact systems, as well as in the study of the operating conditions of network and furnace transformers in power supply systems of energy-intensive technological installations.

Keywords: transformer equipment; load fluctuations; on-load tap-changers; contacts; contact resistance; nonsinusoidal current; reliability.

\section{INTRODUTION}

Reliable functioning of power supply systems for energy-intensive technological electrical installations, such as arc steel-melting furnaces, rolling mills, transmission lines and back-to-back stations, rectifier and inverter substations, as well as facilities for converting the AC frequency $50 \mathrm{~Hz}$ to $60 \mathrm{~Hz}$ (Vyborg HVDC scheme), is an important technical problem [6]-[8], [10]-[12]. It is known that the key and most critical element of such systems are power (furnace) on-load tap-changing transform- ers, the reliability of which is largely determined by the reliability of the on-load tap-changers (OLTC), in particular of their contact systems [2], [6]. This is due to the fact that the maintenance of the directive task of the technological process is achieved by permanent voltage regulation using tap-changing devices and is confirmed by the data on the damageability of transformer equipment in the power supply systems of energy-intensive industries, presented in Table 1.

Table 1. Emergency rate of transformer equipment by its components and voltage ratings

\begin{tabular}{|c|c|c|c|c|c|c|c|c|c|c|c|c|}
\hline \multirow{3}{*}{ Component } & \multicolumn{12}{|c|}{ Voltage ratings, $\mathrm{kV}$} \\
\hline & \multicolumn{2}{|c|}{35} & \multicolumn{2}{|c|}{110} & \multicolumn{2}{|c|}{220} & \multicolumn{2}{|c|}{330} & \multicolumn{2}{|c|}{500} & \multicolumn{2}{|c|}{ Aggregate } \\
\hline & $N$ & $\%$ & $N$ & $\%$ & $N$ & $\%$ & $N$ & $\%$ & $N$ & $\%$ & $N$ & $\%$ \\
\hline Windings & 61 & 30 & 43 & 13 & 10 & 7 & 1 & 8 & $\mathbf{0}$ & $\mathbf{0}$ & 115 & 16 \\
\hline On-load tap changers & 4 & 2 & 61 & 18 & 26 & 19 & 1 & 8 & 5 & 24 & 97 & 13,5 \\
\hline Bushings & 27 & 13 & 77 & 23 & 44 & 32 & 3 & 23 & 7 & 34 & 158 & 22 \\
\hline Other components and causes & $81 / 31$ & $40 / 15$ & $126 / 31$ & $37 / 9$ & $55 / 1$ & $41 / 1$ & $8 / 0$ & $61 / 0$ & $9 / 0$ & $42 / 0$ & $279 / 0$ & $39,5 / 9$ \\
\hline Total & 204 & 100 & 338 & 100 & 136 & 100 & 13 & 100 & 21 & 100 & 712 & 100 \\
\hline
\end{tabular}


The data presented in Table 1 show that the accident rate of transformer equipment due to failures of OLTC is relatively low compared to other components. However, a more detailed analysis shows that defects in OLTC, which are often latent in behavior, are the cause of failures on bushings, windings, other components of transformer equipment and the system as a whole [6].

\section{II.ANALYSIS OF RECENT RESEARCHES}

An essential feature of the OLTC operation is that, in the tap-changing process, they carry out multiple tap-changing operations under conditions of load fluctuations [2], [7], [10]-[12] and a significant incompliance of the power quality characteristics with standardized ones [16]. In the process, non-stationary electromagnetic processes and, accordingly, more severe operating conditions are initiated, which are usually not taken into account when developing OLTC contact systems [1], [2], [4], [5], [9]. In the given case we are dealing with higher harmonics and current unbalance, which, as it is well known, significantly affect the operability of the OLTC contacts, in particular, the contact resistance and switching wear resistance [4], [5], [13], [14]. Therefore, they are imposed by increased requirements.

A significant number of publications are devoted to the study of the effect of load fluctuations on transformer equipment [7], [10]-[12], [15]. Such kind of research has also been carried out for OLTC [10]; however, they require further development due to the specific functioning of their contact systems. In particular, the influence of higher harmonics and unbalance in the current on the parameters of electrical contacts and their reliability has been insufficiently studied.

\section{FORMULATION OF THE WORK PURPOSE}

The purpose of this work is to analyze the operating conditions, to determine the cause-and-effect factors that lead to a decrease in the reliability of OLTC contact systems. The main task of the study is, first and foremost, to determine quantitative characteristics of the influence of load fluctuations on the parameters of the OLTC contacts. The task of the research is also the use of the derived scientific findings for the purpose to modernize operable devices and to develop new engineering and technical solutions.

\section{PRESENTATION OF THE BASIC MATERIAL AND ANALYSIS OF THE OBTAINED RESULTS}

The object of the study was the contact system of the contactor of the switching device of the RNOA$110 / 1250$ type, the appearance of which is shown in Fig. 1, and its electrical characteristics are given in Table. 2.

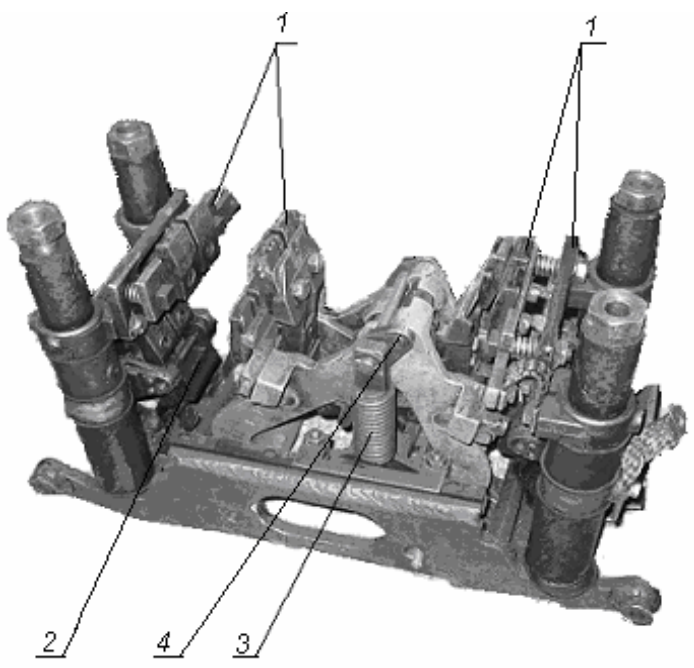

Figure 1. Appearance of the PHOA-110/1250 type OLTC

The following designations are accepted in Figure 1: 1 and 2 are arcing and main contacts, respectively; 3 and 4 are spring and hinge mechanisms, respectively.

To execute the experimental research, a specialized installation has been developed. Its structural diagram is shown in Figure 2.

The following designations are accepted in Figure 2: 1 - switch; 2 - non-sine waveform generator; 3 current THD regulator; 4,5,6 - measuring transducers of power, voltage and current, respectively; 7 - test object (arcing contacts); 8 - transformer; 9 - electric drive of the OLTC; 10 - load; 11 - movie camera; 12 movie camera drive; 13 - block for coordination of starting the all mechanisms drives; 14 - short-circuiter; 15 - chromel-copel thermocouples; 16 - thermal imaging camera.

Table 2. Technical parameters of the investigated switching device of the RNOA-110/1250 type

\begin{tabular}{|c|l|c|}
\hline No. & \multicolumn{1}{|c|}{ Parameter name, measurement unit } & Value \\
\hline $\mathbf{1}$ & Rated voltage, $\mathrm{kV}$ & $\mathbf{1 1 0}$ \\
$\mathbf{2}$ & Rated current, A & $\mathbf{1 2 5 0}$ \\
$\mathbf{3}$ & Mechanical life, thousand switching operations (not less) & $\mathbf{5 0 0}$ \\
$\mathbf{4}$ & Switching life of arcing contacts, thousand switching operations (not less) & $\mathbf{5 0}$ \\
$\mathbf{5}$ & Time of changing over operation from one fixed position to another one, seconds & $\mathbf{3 , 8} \pm \mathbf{2 0} \%$ \\
$\mathbf{6}$ & Number of switching operations before oil change in the contactor, thousand (not less) & $\mathbf{5 0}$ \\
$\mathbf{7}$ & Mass of the on-load tap changer without oil, kg & $\mathbf{1 3 0 0}$ \\
\hline
\end{tabular}




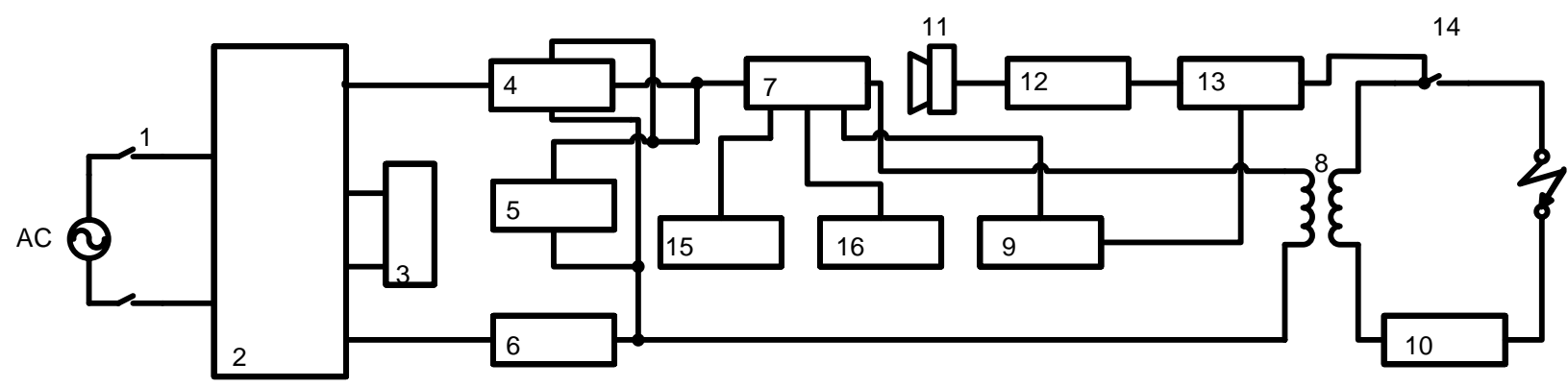

Figure 2. Block diagram of a specialized device for experimental study of electrothermal processes in the contacts of switching devices.

The research were performed using a single-phase model of the on-load tap-changer contactor, which was connected to phase A of the physical model of an electric furnace transformer. Supply voltage was applied to the installation from an $\mathrm{AC}$ power source using a switch 1 . The current THD was adjusted using a shaper 2 controlled by unit 3 . The parameters to be researched were measured with devices 4, 5, 6, 15. A movie camera 11 made filming to visualize the contact opening process and further analysis. The contact heating temperature was measured using chromel-copel thermocouples 15 and thermal imaging camera 16. Unit 13 was used to coordinate the operation of short-circuiter 14 , movie camera 11 , thermocouples 15 and the transformer physical model 8. After each series of tapchanging operations, the contact resistance of the contacts being investigated was measured. The experimental research findings for six values of the THD current are shown in Table 3.

It is known that the contact resistance is a random variable [1], [4], [5], therefore, Table 3 presents the mathematical expectations of the contact conductance, derived from the probabilistic-statistical analysis of several parallel measurements [3]. The mathematical expectation of the contact conductance at certain values of the number of tap-changing operations is selected as the arithmetic mean of the results of parallel measurements:

$$
\bar{\sigma}=\frac{\sum_{i=1}^{n} \sigma_{i}}{n}
$$

where $i$ is the serial number of the measurement; $n$ is the number of parallel measurements; $\sigma_{i}$ is the contact conductance at the $i$-th measurement.

The sample values of the general variance and the root-mean-square error of a single measurement of the contact conductance were calculated using the following formula:
Table 3. Findings of the contact conductance measurements in relative units

\begin{tabular}{|c|c|c|c|c|c|c|}
\hline \multirow{2}{*}{ 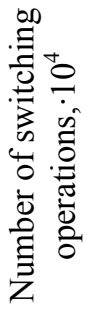 } & \multicolumn{6}{|c|}{ THD, $\%$} \\
\hline & 4,0 & 6,3 & 9,5 & 13,5 & 22,0 & 31,7 \\
\hline 0 & 1,00 & 1,00 & 1,00 & 1,00 & 1,00 & 1,00 \\
\hline 0,1 & 0,99 & 0,99 & 0,99 & 0,97 & 0,97 & 0,97 \\
\hline 0,3 & 0,98 & 0,96 & 0,94 & 0,92 & 0,90 & 0,88 \\
\hline 0,5 & 0,96 & 0,92 & 0,88 & 0,84 & 0,80 & 0,76 \\
\hline 0,7 & 0,94 & 0,88 & 0,83 & 0,77 & 0,72 & 0,66 \\
\hline 0,9 & 0,92 & 0,85 & 0,79 & 0,73 & 0,66 & 0,60 \\
\hline 1,2 & 0,88 & 0,80 & 0,73 & 0,65 & 0,58 & 0,50 \\
\hline 1,6 & 0,86 & 0,77 & 0,68 & 0,60 & 0,51 & 0,42 \\
\hline 2,0 & 0,79 & 0,71 & 0,64 & 0,56 & 0,49 & 0,41 \\
\hline 2,4 & 0,75 & 0,68 & 0,62 & 0,54 & 0,48 & 0,41 \\
\hline 2,7 & 0,71 & 0,65 & 0,59 & 0,53 & 0,47 & 0,41 \\
\hline 3,0 & 0,69 & 0,64 & 0,58 & 0,52 & 0,46 & 0,41 \\
\hline & $=\underline{i=}$ & & & $i=1$ & $i-\bar{\sigma}$ & \\
\hline
\end{tabular}

The correlation function of the contact conductance, depending on the conditional numbers of the measurement series and the number of tap-changing operations, was determined in accordance with the following relationship:

$$
K(l)=\frac{\sum_{l=2}^{m}\left(\sigma_{l-1}-\bar{\sigma}_{l-1}\right)\left(\sigma_{l}-\bar{\sigma}_{l}\right)}{2 \cdot m+1},
$$

where 1 is the serial number of the measurement 
series corresponding to the number of tap-changing operations; $\mathrm{m}$ is the number of experiments in a series of studies.

The probability densities of the contact conductance values (in the form of discrete values of the probability of their falling into the given intervals) were determined according to the expression:

$$
f_{j}\left(\sigma_{i}\right)=\frac{k_{j}}{k \cdot h},
$$

where $k_{j}$ is the number of conductance values falling into the interval $\sigma_{j-1}<\sigma_{i} \leq \sigma_{j} ; k$ is the total number of conductance values obtained in the experiments; $h$ is the interval width $h=\sigma_{j}-\sigma_{j-1}$.

The mathematical expectation and variance of the contact conductance, calculated from experimental findings, depending on the number of tap-changing operations, are shown in Figure 3.

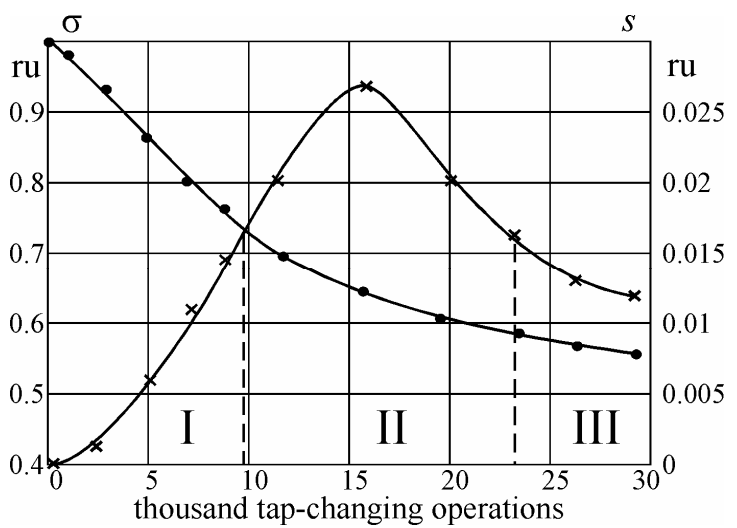

Figure 3. Experimental dependency the contact conductance vs the number of tap-changing operations: - mathematical expectation; $\times$ - variance

An analysis of the invariance indicates that the largest deviations in the contact conductance occur in the range of 10 to 24 thousand tap-changing operations (region II, Figure 3). This can be explained as follows. In the initial stage of testing (region I, Figure 3), the contacts surfaces wear in less degree due to erosion processes. As the number of tap-changing operations increases, the contact wear effect due to arc erosion increases significantly (region II, Figure 3). However, when a certain level of wear is reached, their influence begins to decrease (region III, Figure 3).

Figure 4 shows the graphical dependence of the correlation function depending on the serial number of the series of experiments It is indication of the relationship between the conductance values in adjacent series of experiments at the corresponding values of the number of tap-changing operations (i.e. the influence of values in the previous series of experiments that characterize the degree of wear of the contact surfaces).

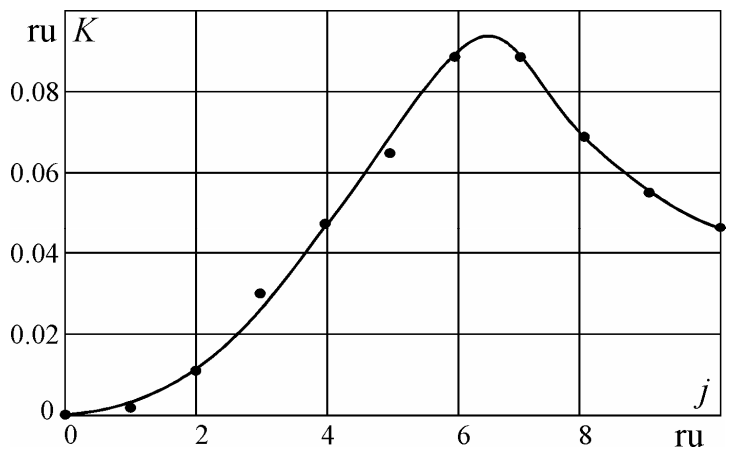

Figure 4. Correlation function of the contact conductance

Figure 5 shows the probability distribution density of the contact conductance, which in this case complies with a uniform law. The presented dependence makes it possible to estimate the number of conductance values that fall into the corresponding intervals.

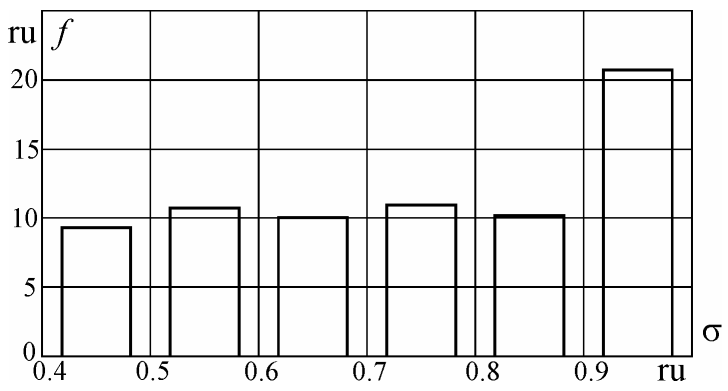

Figure 5. Density of the probability distribution of contact conductance

The analysis of the findings derived made it possible to establish certain regularities of decreasing the reliability of the OLTC in systems with load fluctuations in comparison with general-purpose systems. This can be explained by the fact that, due to electric arc erosion, the alloy structure of the metals used for making the contacts of the OLTC is partially destroyed. In the process, the contact resistance after each series of tap-changing operation increases resulted from a change in the state of the contact surfaces. Ultimately, the contact surfaces take a shape that is significantly different from the initial one.

From $40 \%$ to $80 \%$ of the contact surface is destructed, depending on the duration of the arc discharge during the tap-changing process. Contacts are destroyed most intensively at small distances between them. A significant role plays the cumulative effect when the contact surfaces are repetitively exposed by an electric arc discharge. It is well-known that the shorter the arc during the switching process, the less wear and the higher the reliability of the contact system and the tap-changer as a whole [1], [2], [4], [5]. As an example, Figure 6 shows the contact surfaces exposed 
by arcing after 10,000 tap-changing operations.

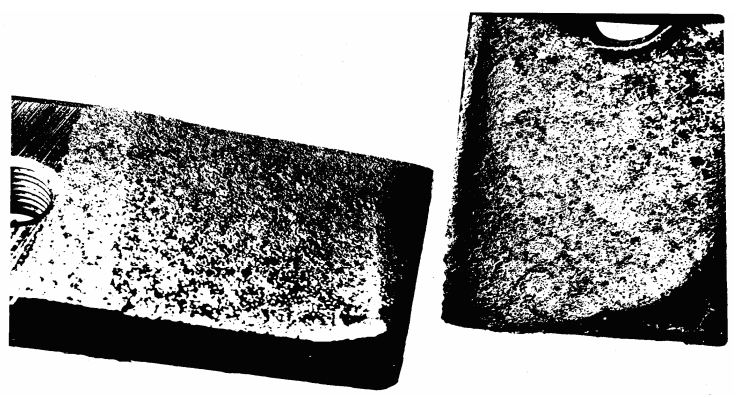

Figure 6. Photographs of the contact surfaces of the OLTC after experimental studies

The results of the studies of the contacts make it possible to formulate technical requirements and technical specifications for the design of new standard versions of OLTC for special purposes and the reconstruction of general-purpose developments.

\section{CONCLUSION}

1. Based on the analysis of the accident rate of transformer equipment in the power supply systems of energy-intensive industrial enterprises, it was found that one of the possible root causes of the development of accidents is damage to switching devices. At the same time, they refer to hidden factors, since when investigating accidents, primary attention is paid to obvious consequences, such as failures bushings, systems for exciting a magnetic field, magnetic circuits, electrodynamic effects, etc.

2. Indicators of accident rates of transformer equipment due to OLTC failures in power supply systems of energy-intensive industries, especially at load fluctuations, are 52\% higher compared to generalpurpose systems. However, if the hidden behavior of the OLTC failures is taken into account, then the given indicator can increase significantly.

3 . In the existing literary sources, there are practically no investigations of switching processes in OLTC for the purpose to determine the cause-and-effect factors of reducing their functional reliability in systems, where the power quality characteristics do not comply with the standard requirements.

4. A specialized device was proposed and a technique was developed for the experimental study of switching processes in tap-changers at variable THD of the exciting current, which made it possible to obtain specific results that explain the cause-and-effect factors of contact damage.

5. The contact resistance directly increases with the increase in the number of tap-changing operations, as well as the THD of the exciting current. It is shown that the largest dispersion in the contact resistance occurs in the range from 10 to 24 thousand tap-changing operations.

\section{REFERENCE}

[1] Aleksandrov, G.N., Borisov, V.V., Kaplan, G.S., i dr. (2000). Teoriya elektricheskikh apparatov: Uchebnik dlya vuzov / pod red. prof. G.N. Aleksandrova. SPb. Izd-vo SPbGTU, 540.

[2] Porudominskiy, V.V. (1974). Ustroystva pereklyucheniya transformatorov pod nagruzkoy M. Energiya. 288.

[3] Vilenkin, S.Ya. (1979). Statisticheskaya obrabotka rezul'tatov issledovaniya sluchaynykh funktsiy. M. Energiya. 250.

[4] Slade, P.G. (2014). Electrical Contacts: Principles and Applications. CRC Press Taylor \& Francis Group, LLC. 1257.

[5] Braunovich, M., Konchits, V.V., Myshkin, N.K. (2007). Electrical Contacts: Principles, Applications and Technology. CRC Press Taylor \& Francis Group, LLC, 660.

[6] Vanin, B.V. (2001). O povrezhdeniyakh silovykh transformatorov napryazheniyem $110-500 \mathrm{kV} \mathrm{v}$ ekspluatatsii [About failures of 110-500 kV power transformers in operation]. Electric stations, 9, 5358, (in Russian).

[7] Zinovkin, V.V., Sisunenko, O.I., Sergiyenko, S.L., Zozulya, D.V. (1994). Nestatsionarnyye rezhimy silovykh transformatorov pri rezkoperemennoy nagruzke [Unsteady state conditions of power transformers under load fluctuation]. Energy and Electrification, 5, 48-52, (in Russian).

[8] Vlasov A.B. (2002). Raschet ekspluatatsionnykh pokazateley nadezhnosti kontaktnykh soyedineniy s pomoshch'yu teplovizionnogo kontrolya [Calculation of reliability operational performances of contact connections using thermal imaging control]. Electrical Engineering, 8, 30-35, (in Russian).

[9] Plokhov, I.V. (2004). Issledovaniye soprotivleniya styagivaniya elektricheskogo kontakta [Study of the constriction resistance of electrical contact]. Electrical Engineering, 5, 13-18 (in Russian).

[10]Zinovkin, V., Kusch, V. (2012). Electromagnetic processes modelling in the electric equipment of the abruptly variable loads systems United States: The Advanced Science, 1, 138-140.

[11]Zinovkin, V., Blyzniakov, O., Vasilieva, E. (2017). Physical Simulation of Electromagnetic Phenomena in Transformer Equipment under Strongly Varying Loads. IEEE: International Conference on Modern Electrical and Energy Systems (MEES), November 15th-17th, Kremenchuk Mykhailo Ostrohradskyi National University, Ukraine, 312-315.

[12]Zinovkin, V., Blyzniakov, O., Vasilieva, E. (2019). Non-stationary electromagnetic processes in power-intensive electrical facilities with highly varying loads. IEEE: International Conference on Modern Electrical and Energy Systems (MEES), September 23th-25th, Kremenchuk Mykhailo 
Ostrohradskyi National University, Ukraine, 362365.

[13]Kotsur, M.I., Yarymbash, D. S., Bezverkhnya, Yu.S., Kotsur, I.M. (2019). New approach for voltage drop estimation in the busbars of workshop networks at higher current harmonics influence. Problemele energeticii regionale, 1, 39, 4356.

[14]Kotsur, M.I., Yarymbash, D.S., Bezverkhnia, Yu.S., Andrienko, A.A., Andrienko, D.S. (2018). Features of influence of the higher harmonics on choice parameters busbars of workshop networks. Works of the Institute of Electrodynamics of the National Academy of Sciences of Ukraine, 2 50,
$51-56$

[15]Zinovkin, V.V., Blyzniakov, O.V. (2018). Determination of Equivalent Quantities of Electromagnetic Field in Massive Ferrous Details of Electric Equipment under Strongly Varying Loads. Electrical Engineering and Power Engineering, 4, 8-16.

[16]EN 50160, (1999). Voltage characteristics of electricity supplied by public distribution systems.

\title{
ДОСЛІДЖЕННЯ ВПЛИВУ НЕСИНУСОЇДАЛЬНИХ НАВАНТАЖЕНЬ НА РОБОТОСПРОМОЖНІСТЬ КОНТАКТІВ ПРИСТРОЇВ РПН
}

\author{
3IHOBKIH B.B. \\ д-р техн. наук, професор, професор кафедри «Електропривод та автоматизація \\ промислових установок» національного університету «Запорізька політехніка», \\ Запоріжжя, Україна, super_znvvv@ukr.net; \\ БЛИЗНЯКОВ О.В. канд. техн. наук, доцент, доцент кафедри «Електричні та електронні апарати» \\ національного університету «Запорізька політехніка», Запоріжжя, Україна, \\ blizn1953@gmail.com;
}

\begin{abstract}
Мета роботи. Встановити кількісні показники впливу несинусоїдальних навантажень на параметри і роботоспроможність контактів пристроїв регулювання напруги трансформаторів під навантаженням (пристроїв РПН) для енергоємних технологічних установок.

Методи дослідження. У роботі використані методи імовірнісно-статистичного аналізу результатів експериментальних досліджень. Експериментальні дослідження виконані з використанням сучасних програмних методів обробки, систематизаиії та візуалізаиії отриманих результатів.

Отримані результати. Аналіз аварійності трансформаторів для енергоємних технологічних установок показав, що пристрої РПН є в багатьох випадках причиною збою в роботі технологічних установок. На прикладі пристрою РПН типу РНОА-110/1250 експериментально встановлено, що несинусоїдальність струму, що є наслідком різкозмінного навантаження, у поєднанні зі зростанням кількості перемикань призводить до збільшення перехідного опору контактів, що істотно знижуе показники надійності і работоспосбность контактів.

Наукова новизна. За даними експерименту і їх статистичної обробки отримана залежність перехідного опору контактів пристрою РПН від коефіиієнта несинусоїдальності струму навантаження при різних кількостях перемикань під навантаженням.

Практична чінність. Результати роботи можуть використовуватись при розробиі нових типів пристроїв РПН спеціального призначення для роботи при різкозмінних навантаженнях, зокрема, підвищення надійності їх контактних систем, а також при дослідженні можливих режимів надійної роботи мережевих $i$ пічних трансформаторів в системах електропостачання енергоємних технологічних комплексів.
\end{abstract}

Ключові слова: трансформаторне обладнання; різкозмінні навантаження; пристрої РПН; контактний опір; несинусоїдальний струм; надійність.

\section{ИССЛЕДОВАНИЕ ВЛИЯНИЯ НЕСИНУСОИДАЛЬНЫХ НАГРУЗОК НА РАБОТОСПОСОБНОСТЬ КОНТАКТОВ УСТРОЙСТВ РПН}

ЗИНОВКИН В.В. д-р техн. наук, профессор, профессор кафедры «Электропривод и автоматизачия промылиленных установок» национального университета «Запорожская политехника», Запорожье, Украина, super_znvvv@ukr.net;

БЛИЗНЯКОВ А.В. канд.техн. наук, доиент, дочент кафедры «Электрические и электронные 
аппараты» национального университета «Запорожская политехника», Запорожье, Украина, е-mail: blizn1953@gmail.com;

Цель работы. Установить количественные показатели влияния несинусоидальных нагрузок на параметры и работоспособность контактов устройств регулирования напряжения трансформаторов под нагрузкой (устройств РПН) для энергоемких технологических установок.

Методы исследования. В работе использованы методы вероятностно-статистического анализа результатов экспериментальных исследований. Экспериментальные исследования выполнены с использованием современных программных методов обработки, систематизации и визуализации полученных результатов.

Полученные результаты. Анализ аварийности трансформаторов для энергоемких технологических установок показал, что устройства РПН являются во многих случаях причиной сбоя в работе технологических установок. На примере устройства РПН типа РНОА-110/1250 экспериментально установлено, что несинусоидальность тока, вызываемая резкопеременными нагрузками, в сочетании с ростом количества переключений приводит к увеличению переходного сопротивления контактов, что существенно снижсает показатели надежности и работоспосбности контактов.

Научна новизна. По данным эксперимента и их статистической обработки получена зависимость переходного сопротивления контактов устройства РПН от коэффициента несинусоидальности тока нагрузки при различных количествах переключений под нагрузкой.

Практическая ченность. Результаты работы могут использоваться при разработке новых типов устройств РПН специального назначения для работы при резкопеременных нагрузках, в частности, повышения надежности их контактных систем, а также при исследовании возможных режимов надежной роботы сетевых и печных трансформаторов в системах электроснабжения энергоемких технологических комплексов.

Ключевые слова: трансформаторное оборудование; резкопеременные нагрузки; устройства РПН; контактное сопротивление; несинусоидальный ток; надежность. 